EXTENDED REPORT

\title{
Tumour necrosis factor receptor gene therapy affects cellular immune responses in collagen induced arthritis in mice
}

\author{
P Mukheriee, S-Y Yang, B Wu, Z Song, L K Myers, P D Robbins, P H Wooley
}

Ann Rheum Dis 2005;64:1550-1556. doi: 10.1136/ard.2004.025619

See end of article for authors' affiliations .....................

Correspondence to: Dr P H Wooley, Department of Orthopedic Surgery, Wayne State University, 1 South, Hutzel Hospital, 4707 St Antoine Blvd., Detroit, Ml 48201, USA; pwooley@wayne. edu

Accepted 3 April 2005 Published Online First 28 April 2004
Background: Collagen induced arthritis $(\mathrm{CIA})$ is an animal model of rheumatoid arthritis (RA) amenable to immunotherapy directed against tumour necrosis factor $\alpha$ (TNF $\alpha$ ).

Objective: To evaluate whether local TNF receptor (TNF-R) gene therapy in DBA/1 mice exerts an influence beyond anti-inflammatory effects. Two measures of $\mathrm{CIA}$ pathogenesis were investigatednamely, immunity to collagen II (CII) 245-270 peptide (the major immunodominant epitope within bovine CII) and the preferential activation of $T$ cell V $\beta 8.2$ variable region receptors in arthritic DBA/ 1 mice.

Methods: DBA/1 mice received single periarticular injections of media or retroviral vectors containing LacZ or human TNF-R into affected arthritic paws at disease onset. Disease severity was monitored, immune responses towards the immunodominant bovine CII 245-270 and subdominant Cll 334-360 peptide epitopes were assessed by ELISA, and $T$ cell V $\beta$ usage was analysed by real time polymerase chain reaction for the LacZ transduced, TNF-R, and viral-free media treated control animals. The therapeutic influence of TNF-R gene transduction was compared with other groups at different times after treatment.

Results: Reduced disease severity was seen 15-35 days after treatment, with a concomitant increase in immunity towards the subdominant Cll 334-360 peptide epitope rather than the immunodominant Cll 245-270 peptide in TNF-R treated animals. Early in the disease, TNF-R treated animals demonstrated a reduction of bias towards the otherwise predominant $\mathrm{V} \beta 8.2 \mathrm{~T}$ cell subset.

Conclusions: TNF-R gene therapy influences cellular immunity in CIA, leading to overall disease amelioration, thus suggesting that TNF inhibition may have therapeutic potential beyond the control of inflammation in RA.
$\mathrm{R}$ heumatoid arthritis (RA) is a chronic systemic autoimmune disease characterised by altered cellular and humoral immune response..$^{12}$ Collagen induced arthritis (CIA) is elicited by the immunisation of disease susceptible $\mathrm{H}-2^{\mathrm{q}}$ and $\mathrm{H}-2^{\mathrm{r}}$ mice with heterologous type II collagen (CII), ${ }^{3-5}$ and is widely used to study the immunological mechanisms relevant to RA. CII reactive CD4+ $\mathrm{T}$ cells and complement fixing anti-CII IgG2a autoantibodies have been implicated as major contributors to the immunopathogenesis of chronic arthritis. ${ }^{5}$ Disease suppression has been observed after administration of monoclonal antibodies to $\mathrm{CD} 4^{6}$ and the $\mathrm{T}$ cell receptor (TCR) variable region $\beta(\mathrm{V} \beta)$ chain, ${ }^{7}$ supporting a critical role for $\mathrm{T}$ cells in CIA. Susceptibility to CIA relies on the ability of major histocompatibility complex (MHC) class II molecules to present specific CII peptides, which lead to the activation of arthritis related CII reactive $\mathrm{T}$ cells. ${ }^{5}$ A major $\mathrm{H}-2^{\mathrm{q}}$ restricted T cell epitope present on bovine, chick, human, and rat CII between amino acids 245 and 270 has been identified as immunodominant and generates the highest immune responses and regulates development of arthritis in disease susceptible DBA/l mice. ${ }^{9-11}$

Beyond MHC restriction, non-MHC factors such as TCR V $\beta$ genes have a crucial role in modulating the susceptibility and progression of CIA, with a preferential use of TCR V $\beta 6$ and $\mathrm{V} \beta 8,{ }^{712}$ similar to experimental autoimmune encephalomyelitis. ${ }^{13}$

Tumour necrosis factor $\alpha(\mathrm{TNF} \alpha)$ is an inflammatory cytokine that contributes to the cytokine cascade in CIA. ${ }^{14}{ }^{15}$ Immunotherapy against $\mathrm{TNF} \alpha$ has been shown to have marked anti-inflammatory effects. ${ }^{16}$ Our objective in this study was to evaluate whether local retrovirus mediated TNF receptor (TNF-R: MOIN-sTNF-Rc-Ig) gene therapy could exert effects beyond its anti-inflammatory activity, and influence the $\mathrm{T}$ cell responses in CIA.

\section{MATERIALS AND METHODS}

\section{Retroviral vector production}

Retroviral vector MOIN-sTNF-Rc-Ig encodes a fusion protein consisting of the extracellular domain of human $55 \mathrm{kDa}$ TNF $\alpha$ receptor covalently linked to the mouse IgGl heavy chain. Soluble human TNF receptor (sTNF-Rc-Ig) was amplified from sTNFRc.Ig plasmid ${ }^{17}{ }^{18}$ using TNF-sR5 and Ig3 oligomers: TNFsR5, 5'-ATCGATGCCATGGGCCTCTCCACCGTG-3'; Ig3, 5'ATCGATTCATTTACCAGGAGA-GTG-3', and inserted into the BamHI site of the retroviral construct $\mathrm{MOIN}^{19}$ resulting in MOIN-sTNF-Rc-Ig. The MFG-LacZ retroviral vectors were made by insertion of LacZ cDNA into $5^{\prime} \mathrm{Ncol}$ and $3^{\prime} \mathrm{BamHl}$ cloning sites of a simplified vector that contains a region of the gag gene (helf-gag) to increase viral titre and the env splice acceptor. High titre virus was produced by transfecting the vector into Phoenix cells, a 293 based amphotropic packaging cell line, and harvesting the supernatant 48 hours after transfection.

\footnotetext{
Abbreviations: $\mathrm{CIA}$, collagen induced arthritis; $\mathrm{Cll}$, collagen type II; DMEM, Dulbecco's modified Eagle's medium; ELISA, enzyme linked immunosorbent assay; INF $\gamma$, interferon $\gamma ;$ MHC, major histocompatibility complex; PCR, polymerase chain reaction; RA, rheumatoid arthritis; TCR, T cell receptor; TNF $\alpha$, tumour necrosis factor $\alpha$; TNF-R, TNF receptor; $\mathrm{V} \beta$, variable region $\beta$
} 


\section{Induction and assessment of CIA}

Native bovine CII (kindly provided by Dr Marie Griffiths, University of Utah) was solubilised at $2 \mathrm{mg} / \mathrm{ml}$ in $0.01 \mathrm{M}$ acetic acid at $4{ }^{\circ} \mathrm{C}$ overnight and emulsified with equal volume of complete Freund's adjuvant (Difco Laboratories, Detroit, MI). Arthritis was induced by intradermal injections of $100 \mu \mathrm{l}$ of emulsion containing $50 \mu \mathrm{g}$ CII at the base of the tails of 6-8 week old female DBA/l LacJ mice (Jackson Laboratory, Bar Harbor, ME). Mice were monitored daily for onset of disease. Mice developing CIA between 20 and 55 days after immunisation were divided on the day of arthritis onset into different treatment groups: (1) MOINsTNF-Rc-Ig treated $(n=23)$, (2) MFG-LacZ treated $(n=13)$, and (3) virus-free media treated controls $(n=20)$. Mice were divided alternately to normalise the onset date.

The first paw (front or hind limb) developing arthritis was given a single periarticular injection of either $1.6 \times 10^{7} \mathrm{pfu} / \mathrm{ml}$ of MOIN-sTNF-Rc-Ig in $100 \mu \mathrm{l}$ of Dulbecco's modified Eagle's medium (DMEM; group 1) or a similar titre of MFG-LacZ in $100 \mu \mathrm{l}$ of DMEM (group 2) at disease onset. Mice in virusfree medium control group received $100 \mu \mathrm{l}$ of DMEM periarticular injection at disease onset. Care was taken to prevent any disruption of skin while administering the injections. We found previously that this dose of MOINsTNF-Rc-Ig improved CIA. ${ }^{20}$

Arthritic animals were clinically assessed daily and paw measurements were recorded by a constant tension caliper (Dyer, Lancaster, PA) five times a week for 7 weeks after disease onset and start of treatment. An established arthritis scoring system ${ }^{21}$ was used to evaluate disease: $0=$ normal appearance and flexion; $1=$ erythema and oedema; $2=$ visible joint distortion; $3=$ ankylosis detectable on flexion. Based on this, each animal could have a maximum score of 12 .

\section{Detection of transgene production}

An enzyme linked immunosorbent assay (ELISA) was performed to evaluate the expression of human TNF-R (hTNF-R) in serum samples collected at days $0,3,7,14,21$, 35, and 49 after the vector injection. The level of the transgene product was calculated by regression analysis from a standard curve included with each assay. X-gal staining ( $\beta$ galactosidase assay) was performed on the mouse paws and major organs such as spleen, liver, lungs, heart, and brain collected from the mice receiving MFG-LacZ injections to evaluate LacZ gene expression systemically. Paws and frozen sectioned major organ tissues were fixed in $2 \%$ formaldehyde $/ 0.2 \%$ glutaraldehyde for 30 minutes before incubation in $1 \mathrm{mg} / \mathrm{ml} \mathrm{X}$-gal solution $\left(5 \mathrm{mM} \quad \mathrm{K}_{3} \mathrm{Fe}(\mathrm{CN})_{6}, \quad 5 \mathrm{mM}\right.$ $\mathrm{K}_{4} \mathrm{Fe}(\mathrm{CN})_{6}, 2 \mathrm{mM} \mathrm{MgCl}_{2}, 0.02 \% \mathrm{NP}_{40}$, and $0.1 \%$ sodium deoxycholate) overnight at $37^{\circ} \mathrm{C}$. Positive LacZ transgene expression was determined by blue tissue staining.

Table 1 Primer sequences of $V \beta$ genes used in this study

\begin{tabular}{ll}
\hline Target & Primer sequences \\
\hline V $\beta 5.1$ & 5'- TGAGTGCCTTGGAGCTAGAG-3' (upstream) \\
& 5'-GCCTGTCCCGGGAGA-3' (downstream) \\
V $\beta 6$ & 5'- GGGGGTGTCAACTATGCTG-3' (upstream) \\
& 5'-GAGACCTTGGGTGGAGTCA-3' (downstream) \\
V $\beta 8.1$ & 5'-GTTGGCTCCCTTCTCAG-3' (upstream) \\
& 5'-TGTGTTGAACCCCTGTCA-3' (downstream) \\
V $\beta 8.2$ & 5'-GCAGCACTGAGAAAGGAGAT-3' (upstream) \\
& 5'-TTGGTCTGGAGGCCTTG-3' (downstream) \\
V $\beta 8.3$ & 5'-GTGTAGGGGCTGGAAATAC-3' (upstream) \\
& 5'-CAACAATGAGCCGGCTT-3' (downstream) \\
V $\beta 16$ & 5'-TTACGGGGGGACTATGCT-3' (upstream) \\
& 5'-GGTGAGTCGTGTCCCTGG-3' (downstream) \\
\hline
\end{tabular}

A

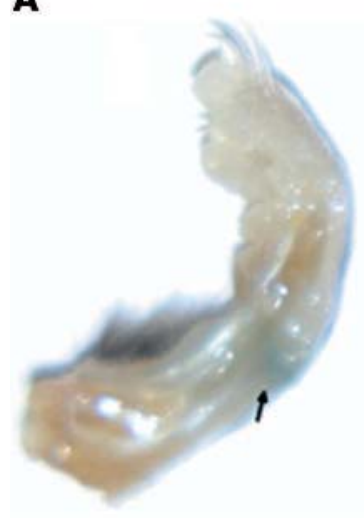

Figure $1 \mathrm{X}$-gal stain to show the expression of LacZ in the mouse paws given MFG-LacZ. (A) A paw at 3 days; and (B) 21 days after viral infection.

\section{Measurement of interferon $\gamma$ (IFN $\gamma$ ) responses to $\mathrm{CII}$ peptide epitopes}

This assay was conducted as previously described. ${ }^{9}$ Lymph nodes obtained at 3, 7, 14, 21, and 49 days after killing the arthritic mice were disrupted to yield single cell suspensions, counted, and assayed for viability. Cells were cultured in duplicate at a final concentration of $5 \times 10^{6}$ cells $/ \mathrm{ml}$ with $100 \mu \mathrm{l}$ of media containing either $100 \mu \mathrm{g} / \mathrm{ml}$ of immunodominant CII $245-270$ peptide, $100 \mu \mathrm{g} / \mathrm{ml}$ of subdominant CII 334-360 peptide, $10 \mu \mathrm{g} / \mathrm{ml}$ concanavalin A, $10 \mu \mathrm{g} / \mathrm{ml}$ lipopolysaccharide, or media alone for 3 days at $37^{\circ} \mathrm{C}$. Responses to the two CII peptides were assessed by measuring the IFN $\gamma$ levels in culture supernatants by the standardised sandwich ELISA technique as previously described, ${ }^{22}$ using purified rat antimouse IFN $\gamma$ antibody and biotin conjugated secondary rat antimouse IFN $\gamma$ antibody (Pharmingen, San Diego, CA).

\section{Analysis of TCR V $\beta$ gene expression by real time polymerase chain reaction (PCR)}

Joints were harvested from arthritic mice post mortem at 3, 7 , 21 , and 49 days after disease onset. Total RNA was extracted using the manufacturer's instructions (Tel-Test, Friendswood, TX, USA), and possible DNA contaminants were removed by RNase-free DNase (RQ1, Promega, Madison, WI, USA) treatment. RNA samples with a ratio $>1.7$ at $260 \mathrm{~nm}$ and $280 \mathrm{~nm}$, measured by a spectrophotometer (Beckman Instruments, Fullerton, CA, USA), were accepted for TCR V $\beta$ analysis.

Firstly, a semiquantitative conventional PCR was used to screen for the most commonly expressed $V \beta$ genes among a battery of $22 \mathrm{~V} \beta$ genes in the paw cDNA samples, generated from control and MOIN-sTNF-Rc-Ig treated mice. Real time reverse transcriptase PCR was performed to assess quantitatively the influence of MOIN-sTNF-Rc-Ig gene transfer on TCR V $\beta$ expression in the paws of the arthritic animals. cDNA was reverse transcribed from $0.5 \mu \mathrm{g}$ total RNA in a $40 \mu \mathrm{l}$ reaction mixture containing $1 \times$ PCR buffer, $500 \mu \mathrm{M}$ of each $\mathrm{dNTP}, 0.5 \mathrm{U} / \mu \mathrm{l}$ RNase inhibitor, $2.5 \mu \mathrm{M}$ random hexamers, $5.5 \mathrm{mM} \mathrm{MgCl}_{2}$, and $1.25 \mathrm{U} / \mu \mathrm{l} \mathrm{MuLV}$ reverse transcriptase (Gibco-BRL, Gaithesburg, MD, USA) in a thermal cycler (Perkin-Elmer Cetus) at $25^{\circ} \mathrm{C} / 10 \mathrm{~min}, 48^{\circ} \mathrm{C} / 25 \mathrm{~min}$, and $95^{\circ} \mathrm{C} /$ $5 \mathrm{~min}$. Real time PCR reaction mixtures $(25 \mu \mathrm{l})$ containing $12.5 \mu \mathrm{l} 2 \times$ SYBR Green Master Mix (PE Biosystems, Foster City, CA, USA), $2 \mu \mathrm{l}$ cDNA, and $400 \mathrm{nM}$ target V $\beta$ (5.1, 6, 8.1, $8.2,8.3$, and 16) gene primer pairs (table 1) were run 


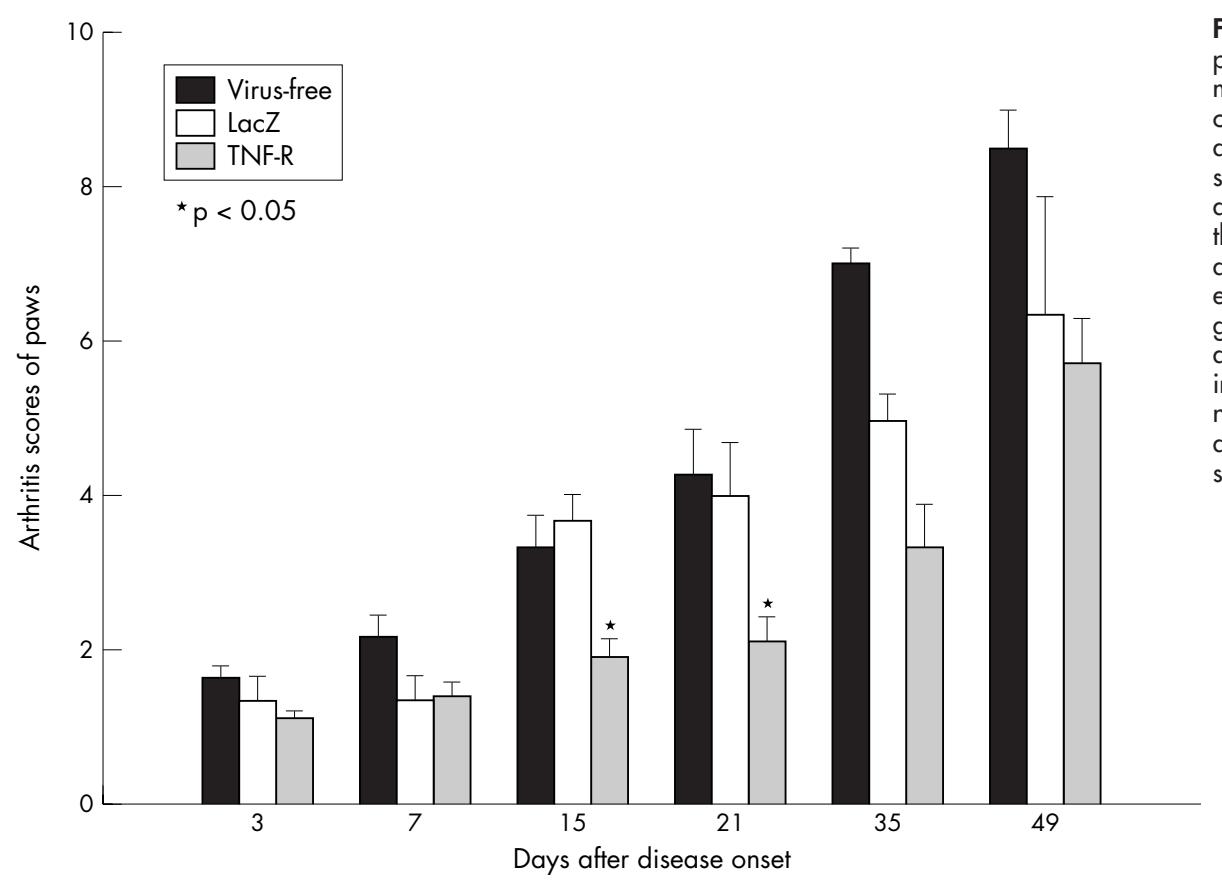

Figure 2 Influence of a single periarticular administration of retrovirus mediated MOIN-sTNF-Rc-lg on the clinical progression of CIA: disease activity represented by the mean paw score was visually scored up to 49 days after disease onset. Mean paw score is the overall average of the paw scores of all animals in each group. Data are expressed as mean (SEM) for each group for each time point. Significant differences among the groups are indicated $(p<0.05)$. The figure shows normalised mean data from three different individual experiments with similar results.

separately in the ABI Prism 7700 Sequence Detector (Applied Biosystems, CA) at $50^{\circ} \mathrm{C} / 2 \mathrm{~min}, 95^{\circ} \mathrm{C} / 10 \mathrm{~min}$ and followed by 40 cycles of $95^{\circ} \mathrm{C} / 15 \mathrm{~s} ; 60^{\circ} \mathrm{C} / \mathrm{min}$. The machine's built-in software recorded values of the threshold cycle $(\mathrm{Ct})$ that showed a statistically significant increase in reporter dye signals $(\Delta R n)$ which were analysed by the vl.7 software (PE Biosystems). Target gene levels were standardised against the housekeeping gene 18S rRNA used as an endogenous control (Invitrogen, Carlsbad, CA, USA). Real time PCR products were run on $1.8 \%$ agarose gels to verify the correct amplification of the target gene.

\section{Statistical analysis}

Group comparisons between TNF-R treated and control mice were performed by the two tailed independent $t$ test using SPSS-PC statistical software (SPSS, Chicago, IL). Comparisons of more than two means were conducted using one way analysis of variance, and p values $<0.05$ were considered to be significant.

\section{RESULTS}

\section{Transgene expression after in vivo gene transfer}

Retrovirus coding for the LacZ gene ( $\beta$-galactosidase) was used as a reporter control. X-gal staining showed positive blue coloured LacZ expressing cells in the MFG-LacZ injected paws at 3 days (fig 1A) and at 21 days (fig 1B) after gene transfer. However, there was no evidence of $\mathrm{X}$-gal positive staining in uninjected paws or remote organs (not shown). The protein level of sTNF-R in the circulation was measured by ELISA at different time points. Three days after disease onset and MOIN-sTNF-Rc-Ig administration, the human sTNF-R level in the circulation was $16.7 \mathrm{pg} / \mathrm{ml}$. This value reduced to $12.7 \mathrm{pg} / \mathrm{ml}$ at 7 days after gene transfer and thereafter was undetectable at 14, 21, and 49 days.
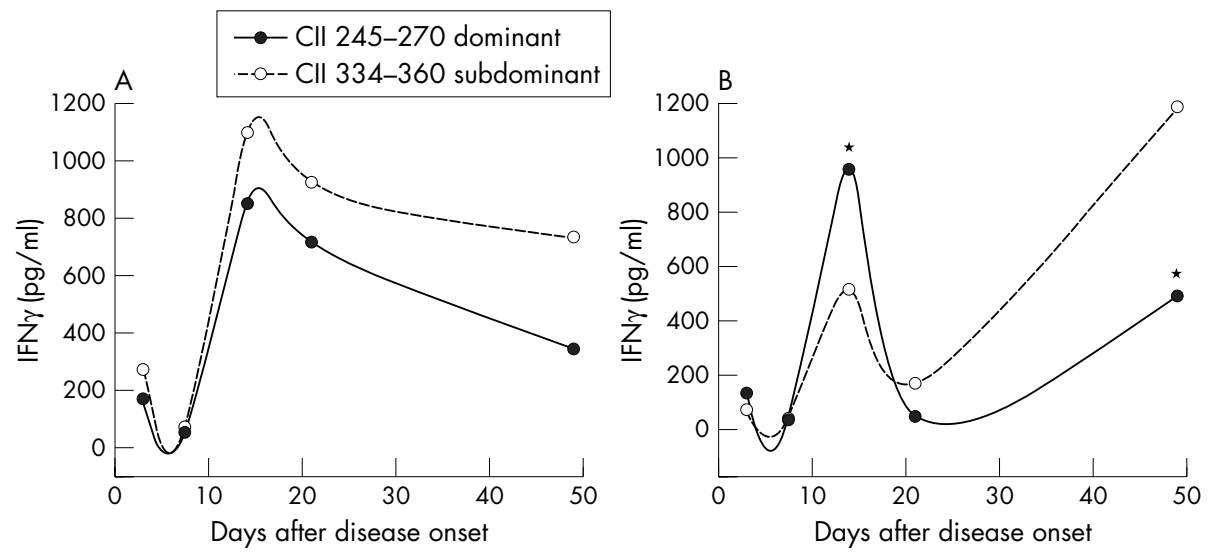

Figure 3 IFN $\gamma$ responses to CII 245-270 and CII 330-360 peptides after MOIN-sTNF-Rc-lg gene therapy: mononuclear cells from lymph nodes of (A) MOIN-sTNF-Rc-lg or (B) media (control) treated mice were cultured with either $100 \mu \mathrm{g} / \mu \mathrm{l}$ of immunodominant CII 245-270 peptide or with subdominant Cll 330-360 peptide for 72 hours. Cells cultured with media and concanavalin A were used as negative and positive controls respectively (not shown). IFN $\gamma$ levels in resulting culture supernatants were measured by ELISA to evaluate Cll peptide epitope usage. TNF-R treated animals showed an enhanced IFN $\gamma$ response towards the subdominant epitopes rather than the immunodominant epitopes (A), while the normal response to the dominant epitope was observed in the controls (B). Data are expressed as mean for each group at each time point. $n=5$ for each time point for both control and TNF-R treated groups. $p<0.05$. 

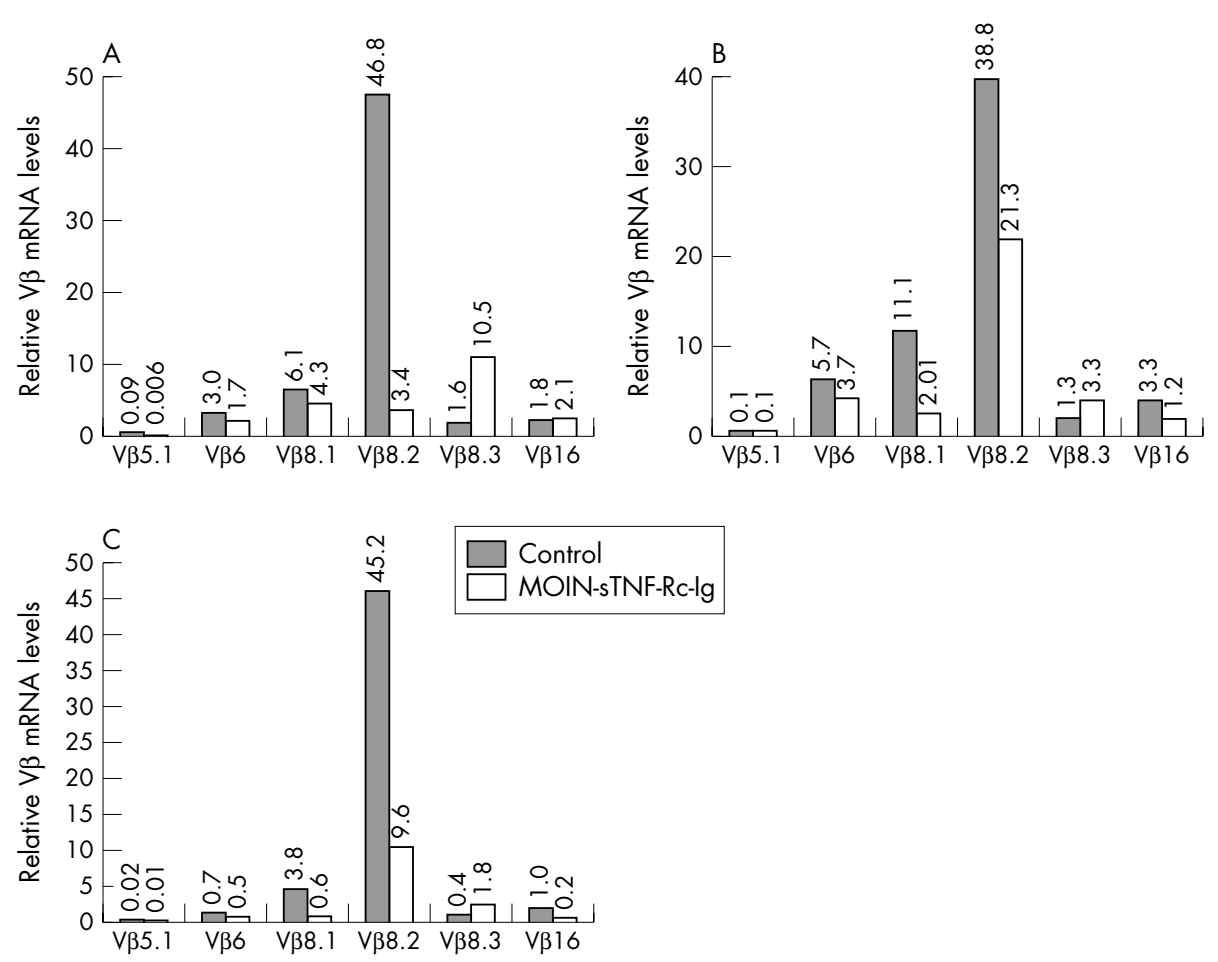

Figure 4 Comparison of $\mathrm{V} \beta$ expression levels in joints of arthritic animals: $c D N A$ made from RNA preparations from (A) injected (B) ipsilateral (C) contralateral joints of media or MOIN-sTNF-Rc-lg injected joints were amplified with different $\mathrm{V} \beta$ primer pairs using real time PCR. The figure shows the relative mRNA expression levels of the six $V \beta$ genes quantitatively analysed normalised against the housekeeping gene 18S rRNA used as an internal control. $n=5$ for both control and TNF-R treated groups.

\section{Retroviral vector mediated periarticular delivery of TNF-R reduces clinical severity of $\mathrm{CIA}$}

On the day of arthritis onset (day 1), CII immunised mice received a single periarticular injection of $1.6 \times 10^{7} \mathrm{pfu} / \mathrm{ml}$ of either MOIN-sTNF-Rc-Ig or LacZ in $100 \mu \mathrm{l}$ of media, or an equal volume of media (virus-free control) into the index affected arthritic paw. Thereafter, all arthritic paws (injected and uninjected contralateral and ipsilateral paws) were scored. A significantly lower mean paw score during 1535 days after disease onset was seen in MOIN-sTNF-Rc-Ig treated DBA/1 mice than in virus-free or LacZ control groups (fig $2, \mathrm{p}<0.05$ ). Histology showed that there was significantly less severe synovitis; bone/cartilage damage, and overall joint destruction in the injected and uninjected arthritic limbs in the TNF-R treated animals relative to controls (data not shown), which was consistent with our previously published results. ${ }^{20}$ These results demonstrated that local periarticular MOIN-sTNF-Rc-Ig delivery had significant effects in ameliorating the overall continuing arthritic disease process up to 35 days after treatment. These experiments were repeated three times for data reproducibility.

TNF-R gene therapy skews the immune response from the immunodominant CII 245-270 peptide to the subdominant CII 334-360 peptide epitope

Culture supernatants of lymph node cells from TNF-R treated mice cultured for 3 days with the subdominant CII 334-360 peptide demonstrated significantly higher levels of IFN $\gamma$ than lymph node cells cultured with the immunodominant CII 245-270 peptide (fig 3A). This enhanced immune response to the subdominant CII 334-360 peptide in the TNF-R treated animals appeared 3 days after disease onset and gene therapy and was sustained for up to 49 days after disease onset (fig $3 \mathrm{~A}$ ). In the control group, the IFN $\gamma$ levels in the culture supernatants obtained from lymph node cells cultured with dominant CII 245-270 peptide were higher than levels observed in lymph node cells cultured with the subdominant CII 334-360 peptide at 3-14 days after disease onset (fig 3B). From 21 days after disease onset, these control animals developed an increased IFN $\gamma$ response towards the subdominant CII 334-360 peptide rather than the immunodominant CII 245-270 peptide. This finding suggests that the TNF-R treated animals showed a diversification of the $\mathrm{T}$ cell responses from the immunodominant CII peptide epitopes towards the subdominant CII epitopes, while in control mice the early immune response to the dominant CII peptide was stronger than to the subdominant peptide. However, an increased $\mathrm{T}$ cell response to the subdominant CII 334-360 peptide epitopes occurred later in the disease. This response pattern, together with the clinical findings, indicates that an early response to the immunodominant CII epitope may be more critical for determining the severity and progression of disease in CIA.

TNF-R gene therapy suppresses V $\beta 8.2$ use in injected, ipsilateral and contralateral joints

cDNA obtained from paws of arthritic animals was amplified with a battery of $22 \mathrm{~V} \beta$ primers by semiquantitative PCR as an initial step to select the predominantly expressed $V \beta$ genes in these samples. Expression of $\mathrm{V} \beta 5.1, \mathrm{~V} \beta 6, \mathrm{~V} \beta 8.1, \mathrm{~V} \beta 8.2$, $\mathrm{V} \beta 8.3$, and $\mathrm{V} \beta 16$ was found to be dominant in the DBA/l arthritic mice (not shown). Subsequently, real time RT-PCR was used to measure quantitatively potential changes in the TCR $V \beta$ repertoire with respect to these genes. V $\beta$ gene expression measured by real time PCR in the arthritic control and TNF-R treated animals was normalised against housekeeping gene 18S rRNA used as an endogenous control.

Real time PCR analysis demonstrated that V $\beta 5.1$, V $\beta 6$, $\mathrm{V} \beta 8.1$, and $\mathrm{V} \beta 8.2$ were decreased in the TNF-R injected joints compared with the control joints (fig 4A). Reduction in V $\beta 8.2$ (known to be preferentially used in CIA ${ }^{12}$ ) was more marked than the changes seen in other $V \beta$ subsets. Interestingly, 


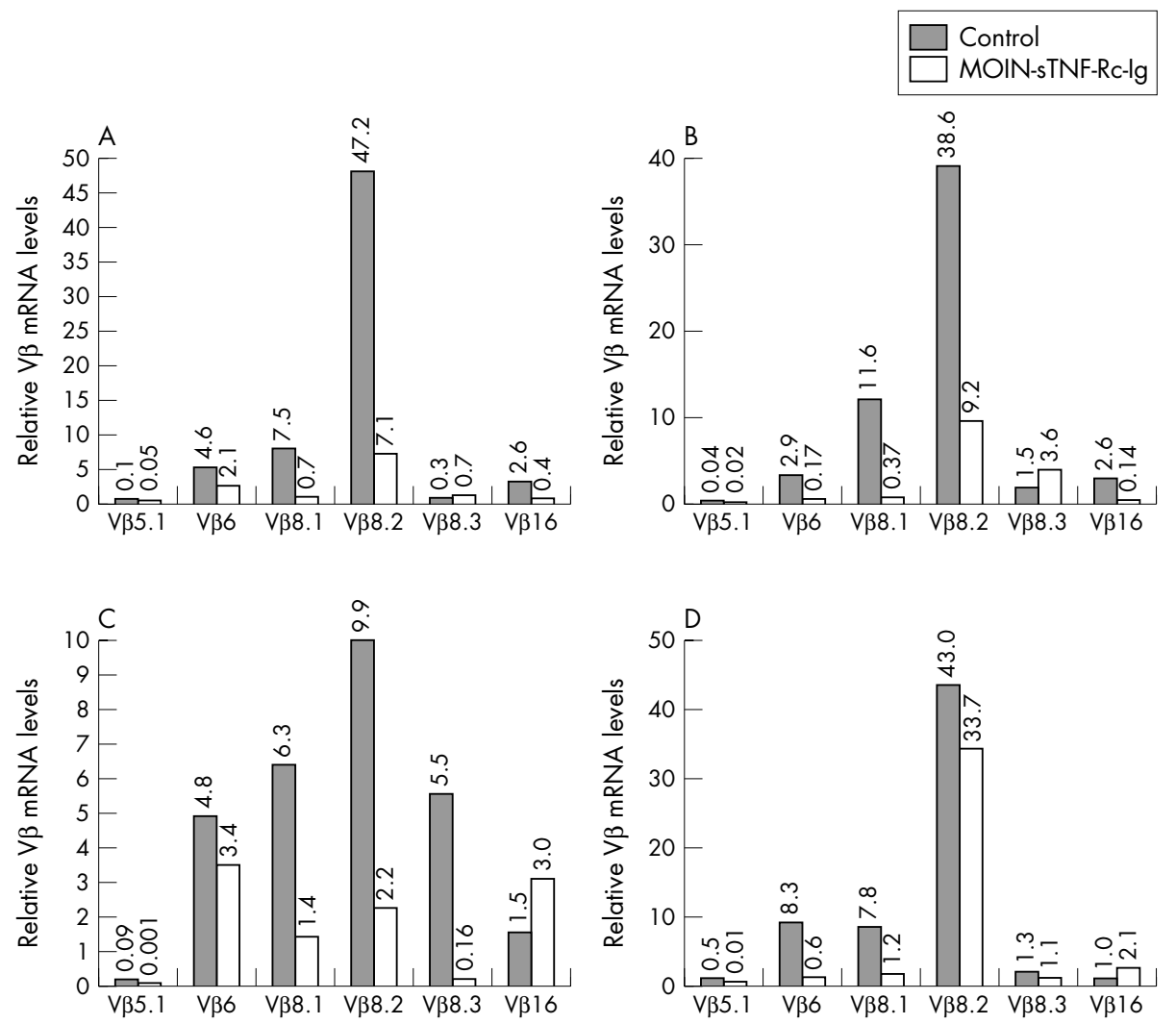

Figure 5 Local TNF-R treatment affects the TCR V $\beta$ repertoire in CIA over time: V $\beta$ mRNA levels in the joints of control and MOIN-sTNF-Rc-lg treated groups were compared by real time RT-PCR at (A) 3; (B) 7; (C) 21; and (D) 49 days after disease onset. CDNA was obtained from RNA preparations from joints of the two groups of mice. Relative $V \beta$ gene expression in both groups, normalised against the housekeeping gene 18S rRNA used as an internal control, is represented. $n=5$ for both control and TNF-R treated groups.

there was also an increase in the use of $\mathrm{V} \beta 8.3$ in joints injected with TNF-R, compared with the controls (fig 4A). Similarly to injected joints, the uninjected ipsilateral (fig 4B) and contralateral (fig 4C) paws of the TNF-R treated animals also showed a marked suppression of the V $\beta 8.2$ mRNA levels relative to all the $\mathrm{V} \beta$ genes tested in the appropriate control joints. However, skewing towards increased V $\beta 8.3$ usage was more prominent in the injected joints than in the uninjected joints of the treated arthritic mice. These data suggest that local TNF-R treatment may suppress the V $\beta 8.2$ gene that is preferentially activated in CIA.

Additionally, the above data suggest that local periarticular TNF-R administration influenced the V $\beta 8.2$ usage in the uninjected arthritic paws of the TNF-R treated animals. This systemic effect after local TNF-R gene therapy is consistent with our histological data (not shown) and our previously published results, ${ }^{20}$ in which periarticular TNF-R administration led to reduced synovitis and decreased pathological bone damage in the arthritic injected and arthritic uninjected joints of treated animals, compared with controls

\section{Temporal effects of periarticular TNF-R gene therapy on the TCR V $\beta$ repertoire}

V $\beta 8.2$ expression was markedly lower in the joints of the TNF-R treated animals than in those of media treated controls up to 21 days after disease onset (fig 5). At 49 days after disease onset, V $\beta 8.2$ mRNA expression was still lower in the paws of the treated animals than in the controls (fig 5D), although the differences at this time were not as marked as those in the earlier stages of the disease (figs $5 \mathrm{~A}, \mathrm{~B}$, and $\mathrm{C}$ ). TNF-R treated animals showed an increased trend for V $\beta 8.3$ use early in the disease (fig $5 \mathrm{~B}$ ). These results indicate that periarticular TNF-R gene therapy led to a trend towards down regulation of the V $\beta 8.2$ gene in the early stages of disease. Later in the disease, the extent of V $\beta 8.2$ suppression diminished, and the increased use of $V \beta 8.3$ seen in treated animals relative to controls was not sustained. The changes in the $\mathrm{V} \beta$ repertoire were reversed in the late stages of the disease, and the positive clinical effects were also diminished. This suggests that the reduction of V $\beta 8.2$ seen in early disease may have a role in the amelioration of CIA.

\section{DISCUSSION}

Progression of CIA depends predominantly upon a Thl response. ${ }^{23}{ }^{24} \mathrm{TNF} \alpha$ has a crucial role in the immune regulatory network of CIA by up regulating interleukin 1 , interleukin 6, and granulocyte monocyte-colony stimulating factor levels, leading to synovial inflammation and joint erosions. $^{21}{ }^{25-27}$ Soluble TNF-R fusion proteins ${ }^{21}{ }^{28}$ and anti$\mathrm{TNF} \alpha$ monoclonal antibody treatment ${ }^{29-31}$ have strong antiinflammatory effects in RA and CIA. ${ }^{16}$ The potential of gene therapy as a therapeutic strategy for CIA and RA is gaining considerable importance in order to circumvent the disadvantages of protein based treatments. ${ }^{32}{ }^{33}$ We have focused on the effects of TNF-R gene therapy beyond its antiinflammatory properties. Retrovirus mediated periarticular delivery of TNF-R at arthritis onset down regulated Thl driven anti-CII IgG2a antibody levels. ${ }^{20}$ Because interplay between both autoantibody and cellular immune responses is crucial to disease pathogenesis, ${ }^{34}$ we examined the effects of local TNF-R treatment on cellular immune responses in CIA.

The immunodominant epitope CII $245-270^{9}{ }^{11}$ can suppress arthritis when used as a tolerogen, and does not stimulate $\mathrm{T}$ cells in disease resistant strains. In contrast, the subdominant 
epitope CII 334-360 peptide does not generate $\mathrm{T}$ cell responses in susceptible DBA/l mice. ${ }^{9}$ We observed a stronger IFN $\gamma$ immune response in TNF-R treated animals to the subdominant CII 334-360 peptide than to the immunodominant CII 245-270 peptide. Moudgil et al demonstrated that diversification of the $\mathrm{T}$ cell response from the initial focused dominant epitope to new epitopes, after priming with the whole antigen, led to protection in adjuvant induced arthritis. ${ }^{35}$ Because we used the native whole CII molecule to induce CIA, the observed increased IFN $\gamma$ responses towards subdominant CII peptide epitopes in TNF-R treated mice might possibly be due to a diversification of the $\mathrm{T}$ cell response. The differences in the responses towards the subdominant epitopes between the treated and control groups suggest that diversification of the immune response away from the immunodominant epitopes early in arthritis could influence the severity of disease. This differs from other autoimmune disease models, where spreading of $\mathrm{T}$ cell responses to new epitopes is associated with aggravation of the continuing disease ${ }^{35} 36$ We recently showed that local TNF-R therapy also down regulates the complement binding anti-CII IgG2a antibody levels in treated animals. ${ }^{20}$

Resistance to arthritis observed in the SWR $\left(\mathrm{H}-2^{\mathrm{q}}\right)$ and RIIIs/J (H-2 $\left.{ }^{\mathrm{r}}\right)$ mice that possess CIA susceptible MHC haplotypes has been attributed to deletions in their $\mathrm{V} \beta$ genome. ${ }^{37-40}$ Previous studies demonstrate the preferential selection of V $\beta 6$ and V $\beta 8.2$ in the arthritic joints of B10.Q ( $\mathrm{H}-$ $2^{\mathrm{q}}$ ) and DBA/1 $\left(\mathrm{H}-2^{\mathrm{q}}\right)$ mice with CIA. ${ }^{41} \mathrm{~V} \beta 5.1, \mathrm{~V} \beta 6, \mathrm{~V} \beta 8.1$, $\mathrm{V} \beta 8.2, \mathrm{~V} \beta 8.3$, and $\mathrm{V} \beta 16$ mRNA were dominantly expressed in the joints of our arthritic animals. Early in the disease, treatment caused suppression of the otherwise predominant V $\beta 8.2$ gene subset in the TNF-R treated animals. Down regulation of V $\beta 8.2$ in both injected and uninjected (contralateral and ipsilateral) joints of arthritic animals suggests that local TNF-R gene therapy exerts systemic effects, consistent with our observations of reduced bone damage in the injected and uninjected arthritic joints of treated mice compared with the controls. ${ }^{20}$ Retroviral vectors encoding a marker LacZ gene, administered periarticularly into arthritic joints at CIA onset, had no influence on the clinical disease. The results suggest that increased $\mathrm{T}$ cell responses towards the subdominant CII peptide epitope, and away from the immunodominant CII epitopes, together with down regulation of the V $\beta 8.2$ bias associated with CIA, lead to improvement in the clinical arthritis seen in TNF-R treated animals.

\section{Authors' affiliations}

P Mukheriee, P H Wooley, Department of Immunology and Microbiology, Wayne State University School of Medicine Detroit, MI 48201, USA

S-Y Yang, B Wu, Z Song, P H Wooley, Department of Orthopedic Surgery, Wayne State University School of Medicine Detroit, MI 48201, USA

L K Myers, Department of Pediatrics, University of Tennessee, Memphis, TN, USA

P D Robbins, Department of Molecular Genetics and Biochemistry, University of Pittsburgh School of Medicine, Pittsburgh, PA 15213, USA

\section{REFERENCES}

1 Choy EH, Panayi GS. Cytokine pathways and joint inflammation in rheumatoid arthritis. N Engl J Med 2001;344:907-16.

2 Lubberts $E$, Joosten LA, van Den BL, Helsen MM, Bakker AC, van Meurs JB, et al. Adenoviral vector-mediated overexpression of IL- 4 in the knee joint of mice with collagen-induced arthritis prevents cartilage destruction. J Immunol 1999; 163:4546-56

3 Wooley PH, Panayi GS, Batchelor JR. Lymphocytotoxins in rheumatoid arthritis: prevalence, lymphocyte specificity, and HLA-DR antigens. Ann Rheum Dis 1981;40:154-6.

4 Yoo TJ, Kim SY, Stuart JM, Floyd RA, Olson GA, Cremer MA, et al. Induction of arthritis in monkeys by immunization with type II collagen. J Exp Med $1988 ; 168: 777-82$.
5 Luross JA. Williams NA. The genetic and immunopathological processes underlying collagen-induced arthritis. Immunology 2001;103:407-16.

6 Chu CQ. Londei M. Induction of Th2 cytokines and control of collagen-induced arthritis by nondepleting anti-CD4 Abs. J Immunol 1996;157:2685-9.

7 Chiocchia G, Boissier MC, Fournier C. Therapy against murine collageninduced arthritis with $\mathrm{T}$ cell receptor $\mathrm{V}$ beta-specific antibodies. Eur J Immunol 1991;21:2899-905.

8 Myers LK, Rosloniec EF, Cremer MA, Kang AH. Collagen-induced arthritis, an animal model of autoimmunity. Life Sc 1997;61:1861-78.

9 Myers LK, Seyer JM, Stuart JM, Terato K, David CS, Kang AH. T cell epitopes of type II collagen that regulate murine collagen-induced arthritis. J Immunol 1993;151:500-5.

10 Malmstrom V, Kjellen P, Holmdahl R. Type II collagen in cartilage evokes peptide-specific tolerance and skews the immune response. J Autoimmun 1998;11:213-21.

11 Brand DD, Myers LK, Terato K, Whittington KB, Stuart JM, Kang AH, et al. Characterization of the T cell determinants in the induction of autoimmune arthritis by bovine alpha 1 (II)-CB 11 in $\mathrm{H}-2 \mathrm{q}$ mice. J Immunol 1994; 152:3088-97.

12 Osman GE, Toda M, Kanagawa O, Hood LE. Characterization of the T cell receptor repertoire causing collagen arthritis in mice. J Exp Med 1993;177:387-95.

13 Offner H, Hashim GA, Vandenbark AA. T cell receptor peptide therapy triggers autoregulation of experimental encephalomyelitis. Science 1991;251:430-2.

14 Nawroth PP, Bank I, Handley D, Cassimeris J, Chess L, Stern D. Tumor necrosis factor/cachectin interacts with endothelial cell receptors to induce release of interleukin 1. J Exp Med 1986;163:1363-75.

15 Haworth C, Brennan FM, Chantry D, Turner M, Maini RN, Feldmann M. Expression of granulocyte-macrophage colony-stimulating factor in rheumatoid-arthritis - regulation by tumor-necrosis-factor-alpha. Eur J Immunol 1991;21:2575-9.

16 Quattrocchi E, Walmsley M, Browne K, Williams RO, Marinova-Mutafchieva L, Buurman W, et al. Paradoxical effects of adenovirus-mediated blockade of TNF activity in murine collagen-induced arthritis. J Immunol 1999;163:1000-9.

17 Ghivizzani SC, Lechman ER, Kang R, Tio C, Kolls J, Evans CH, et al. Direct adenovirus-mediated gene transfer of interleukin 1 and tumor necrosis factor alpha soluble receptors to rabbit knees with experimental arthritis has local and distal anti-arthritic effects. Proc Natl Acad Sci 1998;95:4613-18.

18 Peppel K, Crawford D, Beutler B. A Tumor-necrosis-factor (TNF) receptor-lgG heavy-chain chimeric protein as a bivalent antagonist of TNF activity. J Exp Med 1991:174:1483-9.

19 Kim SH, Yu SS, Park JS, Robbins PD, An CS, Kim S. Construction of retroviral vectors with improved safety, gene expression, and versatility. J Virol 1998;72:994-1004.

20 Mukheriee P, Wu B, Mayton L, Kim SH, Robbins PD, Wooley PH. TNF receptor gene therapy results in suppression of $\lg \mathrm{G} 2 \mathrm{a}$ anticollagen antibody in collagen induced arthritis. Ann Rheum Dis 2003;62:707-14.

21 Wooley PH, Dutcher J, Widmer MB, Gillis S. Influence of a recombinant human soluble tumor-necrosis-factor receptor Fc fusion protein on type-ll collagen-induced arthritis in mice. J Immunol 1993;151:6602-7.

22 Wooley PH, Schaefer C, Whalen JD, Dutcher JA, Counts DF. A peptide sequence from platelet factor 4 (CT-112) is effective in the treatment of type II collagen induced arthritis in mice. J Rheumatol 1997;24:890-8.

23 Holmdahl R, Bailey C, Enander I, Mayer R, Klareskog L, Moran T, et al. Origin of the autoreactive anti-type II collagen response. II. Specificities, antibody isotypes and usage of $\mathrm{V}$ gene families of anti-type II collagen B cells. J Immunol 1989;142:1881-6.

24 Arend WP, Dayer JM. Inhibition of the production and effects of interleukin-1 and tumor necrosis factor alpha in rheumatoid arthritis. Arthritis Rheum 1995;38:151-60.

25 Brennan FM, Chantry D, Jackson A, Maini R, Feldmann M. Inhibitory effect of TNF alpha antibodies on synovial cell interleukin-1 production in rheumatoid arthritis. Lancet 1989:2:244-7.

26 Butler DM, Maini RN, Feldmann M, Brennan FM. Modulation of proinflammatory cytokine release in rheumatoid synovial membrane cell cultures. Comparison of monoclonal anti TNF-alpha antibody with the interleukin-1 receptor antagonist. Eur Cytok Netw 1995;6:225-30.

27 Whalen JD, Lechman EL, Carlos CA, Weiss K, Kovesdi I, Glorioso JC, et al. Adenoviral transfer of the viral IL-10 gene periarticularly to mouse paws suppresses development of collagen-induced arthritis in both injected and uninjected paws. J Immunol 1999;162:3625-32

28 Moreland LW, Baumgartner SW, Schiff MH, Tindall EA, Fleischmann RM, Weaver AL, et al. Treatment of rheumatoid arthritis with a recombinant human tumor necrosis factor receptor (p75)-Fc fusion protein. N Engl J Med 1997;337:141-7

29 Thorbecke GJ, Shah R, Leu CH, Kuruvilla AP, Hardison AM, Palladino MA Involvement of endogenous tumor necrosis factor alpha and transforming growth factor beta during induction of collagen type II arthritis in mice. Proc Natl Acad Sci 1992;89:7375-9.

30 Elliott MJ, Maini RN, Feldmann M, Long-Fox A, Charles P, Bijl H, et al. Repeated therapy with monoclonal antibody to tumour necrosis factor alpha (cA2) in patients with rheumatoid arthritis. Lancet 1994:344:1 125-7.

31 Rankin EC, Choy EH, Kassimos D, Kingsley GH, Sopwith AM, Isenberg DA et al. The therapeutic effects of an engineered human anti-tumour necrosis factor alpha antibody (CDP571) in rheumatoid arthritis. Br J Rheumatol 1995;34:334-42

32 Verma IM. Somia N. Gene therapy-promises, problems and prospects. Nature 1997;389:239-42.

33 Ghivizzani SC, Lechman ER, Tio C, Mule KM, Chada S, McCormack JE, et al. Direct retrovirus-mediated gene transfer to the synovium of the rabbit knee: implications for arthritis gene therapy. Gene Ther 1997;4:977-82. 
34 Taylor PC, Plater-Zyberk C, Maini RN. The role of the B cells in the adoptive transfer of collagen-induced arthritis from DBA/1 (H-2q) to SCID $(\mathrm{H}-2 \mathrm{~d})$ mice. Eur J Immunol 1995;25:763-9.

35 Moudgil KD, Chang TT, Eradat H, Chen AM, Gupta RS, Brahn E, et al. Diversification of $T$ cell responses to carboxy-terminal determinants within the $65-\mathrm{kD}$ heat-shock protein is involved in regulation of autoimmune arthritis. J Exp Med 1997; 185:1307-16

36 Vanderlugt $\mathrm{CL}$, Miller SD. Epitope spreading in immune-mediated diseases: implications for immunotherapy. Nat Rev Immunol 2002;2:85-95.

37 Haqqi TM, Banerjee S, Anderson GD, David CS. RIII S/J (H-2r). An inbred mouse strain with a massive deletion of $T$ cell receptor $V$ beta genes. J Exp Med 1989; 169:1903-9.
38 Haqqi TM, Banerjee S, Jones WL, Anderson G, Behlke MA, Loh DY, et al. Identification of T-cell receptor $\mathrm{V}$ beta deletion mutant mouse strain $\mathrm{AU} / \mathrm{ss} \mathrm{J}(\mathrm{H}$ 2q) which is resistant to collagen-induced arthritis. Immunogen 1989:29:180-5.

39 Haqqi TM. David CS. T-cell receptor V beta genes repertoire in mice. Possible role in resistance and susceptibility to type II collagen-induced arthritis. $J$ Autoimmun 1990;3:113-21.

40 Nabozny GH, Bull MJ, Hanson J, Griffiths MM, Luthra HS, David CS Collagen-induced arthritis in T cell receptor $V$ beta congenic B10.Q mice. J Exp Med 1994; 180:517-24.

41 Haqqi TM, Anderson GD, Banerjee S, David CS. Restricted heterogeneity in Tcell antigen receptor $V$ beta gene usage in the lymph nodes and arthritic joints of mice. Proc Natl Acad Sci 1992;89:1253-5.

\section{1 th European Forum on Quality Improvement in Health Care}

26-28 April 2006, Prague, Czech Republic For further information please go to: www.quality.bmipg.com Book early to benefit from a discounted delegate rate 